\title{
Pelatihan Pemanfaatan Limbah Plastik Untuk Pemuda dan Remaja Masjid
}

\author{
Idel Waldelmi $^{1^{*}}$, Afvan Aquino ${ }^{2}$, Aljufrii ${ }^{3}$ \\ 1,2Program Studi Manajemen, Fakultas Ekonomi Universitas Lancang Kuning, Indonesia \\ ${ }^{3}$ Program Studi Akuntansi, Fakultas Ekonomi Universitas Lancang Kuning, Indonesia \\ Email: 1idelwaldelmi@unilak.ac.id, 22afvanaquino@unilak.ac.id, ${ }^{3}$ aljufri@unilak.ac.id
}

\section{INFORMASI ARTIKEL}

\section{Data artikel:}

Naskah masuk, 24 Oktober 2021

Direvisi, 27 Desember 2021

Diiterima, 17 Januari 2022

\section{Kata Kunci:}

Youth

Training

Plastik Waste

\begin{abstract}
ABSTRAK
Abstract- The basis for consideration from the service team is to go down to the community in an effort to deal with plastic waste, both plastic waste in households and the surrounding community. The target of the activity is the youth and youth of the mosque with the hope of building creativity and awareness in the youth and youth of the mosque in the neighbourhood of RT/RW 002/012, Sidomulyo Timur Sub-district, Marpoyan Damai District, Pekanbaru. In its implementation, it is carried out by providing counselling on the usefulness value of plastic waste, and training on the value creation of plastic waste as well as assistance/practice in making handicrafts from plastic waste. From the implementation of the service that has been carried out, the results show that there is an increase in knowledge, understanding and the desire of youth and community leaders for the treatment of waste.
\end{abstract}

\section{Korespondensi:}

Abstrak- Dasar pertimbangan dari tim pengabdian untuk turun ke masyarakat adalah dalam upaya penanggulangan limbah sampah plastik baik limbah plastik yang ada di rumah tangga maupun lingkungan masyarakat sekitar. Target dari kegiatan yakni pemuda dan remaja masjid dengan harapan terbangunnya kreativitas dan kesadaran pada pemuda dan remaja masjid di lingkungan RT/RW 002/012, Kelurahan Sidomulyo Timur, Kecamatan Marpoyan Damai, Pekanbaru. Dalam pelaksanaannya dilakukan dengan memberikan penyuluhan akan nilai kemanfaatan dari sisa sampah plastik, dan pelatihan akan krestivitas nilai akan sampah plastik serta pendampingan/praktek pembuatan kerajinan dari sisa sampah plastik. Dari pelaksanaan pengabdian yang telah dilaksanakan didapatkan hasil yang menyatakan bahwa bertambahnya pengetahuan, pemahaman dan adanya keinginan dari pemuda dan tokoh masyarakat akan pengolahan dari limbah tersebut.

\section{Idel Waldelmi}

Program Studi Manajemen, Fakultas Ekonomi, Universitas Lancang Kuning Riau Jl. Yos Sudarso KM 08 Rumbai, Pekanbaru, Indonesia 


\section{PENDAHULUAN}

Problematika sampah sampai dengan saat ini memang menjadi isu sentral dikalangan masyarakat khususnya di kota Pekanbaru, sampah saat ini bisa tontonan harian yang bisa disaksikan dengan mata terbuka di sepanjang jalan kota Pekanbaru, bahkan sudah menggunung dan aroma yang setiap saat bisa dinikmati setiap masyarakat yang melewati jalan-jalan yang penuh dengan tumpukkan sampah (Horodytska et al., 2018). Terlepas apakah sampah menjadi problem di Pekanbaru yang selalu digaungkan dengan sebutan sebagai kota madani sekaligus kota metropolitan selalu menjadi pilihan dan pembicaraan di kalangan masyarakat apalagi masyarakat yang ingin menggais keberlanjutan hidup/menyambung di kota Pekanbaru (Liu et al., 2019). Sampah juga bisa menjadi alat politik yang ingin tebar pesona dan saling menyudutkan atau bahkan menjatuhkan. Sampah juga menjadi sebuah alternatif yang memiliki nilai ekonomi yang bisa menghidupkan ekonomi masyarakat tersebut, namun harus siap bergelimang bahkan terjun langsung untuk mendapatkan nilai ekonomi dari sampah tersebut (Wedayani, 2018).

Pesona sampah di Pekanbaru terus dibicarakan khususnya masyarakat yang menggais kehidupan dari sampah tersebut, namun sampah yang begitu luar biasa banyaknya tidak mampu di kelola oleh masyarakat, bahkan sekelas pemerintah kewalahan dalam menyeleseikan problem tersebut. Sampah dikategorikan dalam sampah organik dan sampah non organik Sampah saat ini di Pekanbaru bersatu antara sampah organik dan tidak organik

Permasalahan sampah dikota Pekanbaru memang tidak lepas dari tingkat perkembangan Pekanbaru yang cukup tajam dari jumlah penduduk yang dari tahun ke tahun selalu mengalami peningkatan. Hal ini tentu memberikan dampak terhadap kebutuhan masyarakat di Pekanbaru, terutama dalam problem sampah yang tempat untuk mengelola sampah secara mandiri yang sifatnya terbatas oleh lahan yang ada di setiap rumah masyarakat. Pada akhirnya masyarakat memilih untuk membuang sampah di tempat sampah umum yang disediakan oleh pemerintah hingga tempat pembuangan sampah liar, sehingga peningkatan dan keterbatasan lahan inilah yang mungkin menjadi problem dalam peningkatan jumlah sampah di kota Pekanbaru (Ismanto, 2016).

$$
\text { Pengabdian program kemitraan }
$$
masyarakat ini dilaksanakan dilingkungan RT/RW 002/012 Kecamatan Marpoyan kelurahan sidomulyo timur tepatnya di jalan dirgantara. Problem sampah juga muncul di lingkungan masyarakat tersebut. Tempat pembuangan sampah memang yang resmi tidak ada tempatnya namun tetap saja sampah itu dibuang begitu saja di tepi- tepi jalan lingkungan Jl. Dirgantara tersebut. Pada kesempatan ini kami dari tim pengabdian mencoba untuk membangun komunikasi dengan tokoh masyarakat lingkungan tersebut akan pengelolaan sampah tersebut, dan hasilnya ibarat gayung bersambut yang mengarah pada kerjasama dengan masyarakat, salah satunya dengan memberdayakan pemuda dan remaja yang ada untuk dapat memanfaatkan sampah rumaham yang ada dilingkungan tersebut untuk bisa di jadikan nilai yang lebih dan kemanfaatan akan lingkungan tersebut (Budiarti et al., 2018).

Masyarakat yang ada dilingkungan RT/RW 002/012 ini lebih suka yang sifatnya instan/membeli barang yang sudah ada, karena secara ekonomi menenggah ke atas. Namun aktifitas dirasa perlu, dimana sebagian besar warga masyarakatnya banyak tinggal/ menempati lingkungan tersebut dan pemuda /remaja juga banyak di rumah, karena tidak menyadari nilai manfaat dari sisa pembuangan makanan/bungkusan dari rumah tangga bisa didaur ulang/dimanfaatkan kembali oleh rumah tangga tersebut (Rakib et al., 2019).

Jumlah masyarakat di lingkungan RT/RW 002/012 ini terdiri atas 38 kepala keluarga 
yang terdata dari sumber lingkungan RT/RW tersebut, lebihnya banyak masyarakat yang keluar masuk/bukan masyarakatan tempatan, namun menetap di lingkungan RT/RW tersebut. Aktifitas ini dirasa dapat memberikan manfaat bagi masyarakat pada umumnya dan pemuda/remaja yang ada di lingkungan tersebut, karena pemuda dan remaja juga banyak dan sebagian besar juga aktif di masjid.

Kegiatan dari pelatihan pemanfaatan limbah sampah plastik bagi pemuda dan remaja masjid ini bertujuan untuk memberikan kegiatan yang edukatif akan penangganan dan pemanfaatan sampah plastik di lingkungan RT/RW tersebut, sekaligus untuk merangsang kreatifitas dan pemberdayaan masyarakat dalam menggolah dan memanfaatkan sampah limbah plastik yang lebih bernilai fungsional (Pakaya \& Muhrim, 2020).

Pemanfaatan sampah plastik menjadi solusi yang cukup baik untuk mengubah sampah menjadi barang yang bermanfaat kembali, bahkan dapat memberikan nilai tambah ekonomi dan dapat dikreasikan (Budiarti et al., 2018). Pemanfaatan sampah plastik tinggal bagaimana memanfaatkan kreatifitas menjadi sebuah kerajinan. Banyak hal yang dapat memberikan nilai ekonomi pada sampah plastik yang hampir setiap hari kita jumpai dalam kehidupan kita, adapun kreatifitas itu berupa gantungan jilbab, bunga plastik tempat tumbuhan hidroponik, dompet, lampu hias, tempat pensil, keranjang, tas belanja dan masih banyak lainnya serta hasil pengabdian yang dilakukan oleh (Pakaya \& Muhrim, 2020) bahwasannya tujuan dari pengolahan sampah plastik yakni untuk meningkat kesejahteraan dan mengurangi timbunan sampah plastik, serta peningkatan pengetahuan, pemahaman dan keinginan dari masyarakat akan kepedulian akan lingkungan (Rakib et al., 2019).

Dengan adanya program ini dapat nantinnya memberikan nilai peningkatan kreativitas sampah plastik bagi pemuda dan remaja masjid khusunya dilingkungan RT/RW 002/012 Kelurahan Sidomulyo timur.
Diharapkan nantinya dengan ada pemanfaatan dari sampah plastik dapat diolah dengan baik baik itu untuk media tanam baik itu dilingkungan masjid oleh pemuda dan remaja masjid (Budiarti et al., 2018), taman-taman di lingkungan masyarakat dan lainnya.

Dari hasil survey dan diskusi dengan pemuda dan remaja masjid yang telah dilakukan pada lingkungan masyarakat RT/RW 002/012, ternyata permasalahan yang dihadapi pemuda dan remaja masjid di jalan Dirgantara dalam penanggann sisa limbah sampah plastik yakni: (1) Tidak adanya kemauan dari para pemuda dan remaja dalam menggerakkan pemuda dan remaja yang ada di lingkungan RT/RW 002/012 dan lingkungan Masjid. (2) Kurangnya informasi dan pengetahuan yang lebih relevan bagaimana dalam mengelola sampah plastik yang ada dilingkungan RT/RW 002/012, (3) Kurangnya motivasi dan kemauan dari pemuda dan remaja yang ada di lingkungan RT/RW 002/012 (4) Kurangnya minat dari pemuda dan remaja masjid akan nilai kemanfaatan dari sisa limbah plastik yang ada dilingkungan RT/RW 002/012 dan (5) Budaya instan yang lebih dominan akan kemanfaatan dari sisa sisa limbah sampah rumah tangga di lingkungan RT/RW 002/012, sehingga lebih senang membeli yang sudah jadi ketimbang berupaya menjadikan sisa sampah yang ada di rumah tangga itu sendiri (Ng, 2019).

Upaya yang dapat dilakukan untuk bisa menjadi solusi dari permasalahan di jumpai dalam program kemitraan masyarakat yang berkaitan dengan nilai kemanfaatan dari nilai sisa limbah plastik yang ada dilingkungan RT/RW 002/012 bagi pemuda dan remaja masjid di jalan diantaranya yaitu: (1) Memberikan pencerahan akan nilai kemanfaatan dan nilai ekonomi dari sisa sisa sampah rumah tangga yang ada dilingkungan RT/RW 002/012; (2) Memberikan pelatihan akan apa saja dapat dijadikan kerajinan dari setiap sisa sampah plastik yang tersebar baik dari rumah tangga dan lingkungan RT/RW 002/012; (3) Memberikan pemahaman akan 
dampak positif dan negatif dari sisa sampah yang ada di rumah tanggan dan tersebar di lingkungan RT/RW 002/012 (Li et al., 2020).

Adapun yang menjadi target luaran dari hasil pengabdian program kemitraan masyarakat di lingkungan RT/RW 002/012 Kecamatan Marpoyan Damai Kelurahan Sidomulyo timur ini yakni: (1) Bagi pemuda dan remaja masjid yang ada dilingkungan RT/RW terbangunnya kreativitas yang memberikan nilai, peduli dengan lingkungan;

(2) Terbangunnya kesadaran akan kemanfaatan dari sisa sampah rumah tangga dan nilai ekonomi bagi masyarakat sekitar serta pemuda dan remaja yang memiliki pengetahuan, pemahaman dan mampu memberikan sikap peduli akan nilai dari sisa sampah tersebut; (3) Bagi lembaga (Universitas Lancang Kuning) menjadi kampus yang peduli akan lingkungan dan referensi dalam kepedulian akan lingkungan (Anuar Sharuddin et al., 2016).

\section{METODE PELAKSANAAN}

Mitra Program Kemitraan Masyarakat ini dilaksanakan di lingkungan RT/RW 002/012 Kecamatan Marpoyan Damai Kelurahan Sidomulyo Timur Pekanbaru Riau, dalam hal Pemanfaatan sampah plastik pada pemudan dan Remaja masjid.

Untuk yang menjadi sasaran dari Program Kemitraan Masyarakat ini yakni Pemuda dan Remaja masjid Khususnya dan Masyarakat pada umumnya yang ada dilingkungan RT/RW 002/012 Kecamatan Marpoyan Damai Kelurahan Sidomulyo Timur Pekanbaru Riau.

Tahapan pelaksanaan program kemitraan masyarakat ini yaitu: (1) Survey pada lokasi program kemitraan masyarakat; (2) Penentuan lokasi dan sasaran yang ingin di capai dalam program kemitraanm masyarakat ini. Tahapan Pelaksanaan Program kemitraan masyarakat/ pengabdian: (1) Memberikan penyuluhan tentang nilai kemanfaatan dari sisa sampah plastik baik yang ada di rumah tangga dan lingkungan sekitar; (2) Pelatihan kreativitas sampah plastik yang ada di rumah tangga dan lingkungan masyarakat (kerajinan);
Pendampingan/praktek pembuatan kerajinan dari sisa sampah plastik.

Adapun yang akan menjadi tolak ukur dari keberhasilan dari program kemitraan masyarakat dapat dilihat dari sisi: (1) Partisipasi masyarakat yang cukup tinggi, Hal ini tentunya akan menjadi tolak ukur akan keberhasilan program kemitraan ini, dimana akan muncul berbagai macam apa yang menjadi keinginan dari pemuda dan remaja serta masyarakat akan kemanfaatan sampah rumah tangga yang di lingkungan masyarakat; (2) Peningkatan pengetahuan, pemahaman untuk merealisasikannya di lingkungan masyarakat dalam pengolahan sisa sampah plastik; (3) Adanya keinginan masyarakat untuk meminta tim pengabdian/kemitraan ini agar bisa dilanjutkan ditahap berikutnya dengan konsep yang lain, namun tetap pemberdayaan sampah.

\section{HASIL DAN PEMBAHASAN}

Pemanfaatan limbah sampah plastik dengan kondisi saat ini menjadi solusi altenatif dalam mengurai problem yang terjadi di berbagai daerah di riau, termasuk itu Kota Pekanbaru sendiri. Limbah sampah plastik dapat menjadi diuraikan dengan berbagai upaya yang dapat dilakukan oleh pemerinta/ swasta/Lembaga riset dan pengguna lainnya yang mengarah pada nilai ekonomi atau pendapatan. Limbah sampah plastik selain menjadi problem yang harus segera di tanggani dengan baik juga menjadi problem bagi lingkungan yang ada serta dampak lain yang ditimbulkan dari problem sampah/limbah ini.

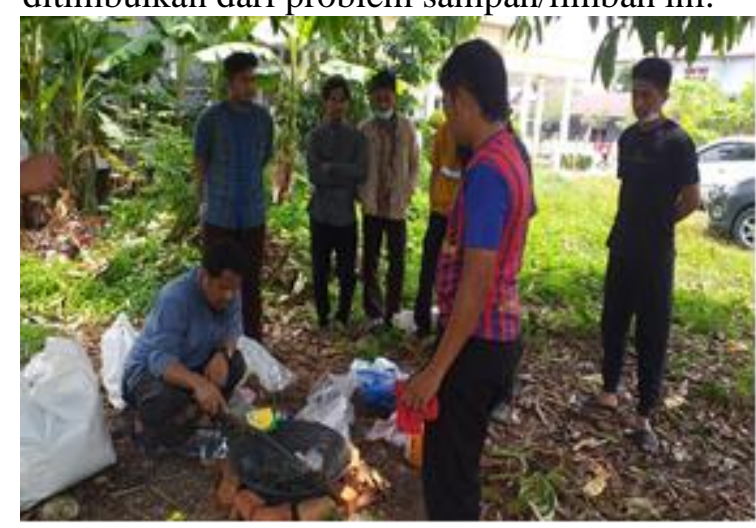

Gambar 1. Proses Pengolahan limbah plastik 
Limbah sampah plastik dapat menjadi solusi bila dapat ditangani di tangan yang tepat dan ditempat yang tepat. Hal ini perlu di tanggani oleh tangan tangan yang peduli dengan lingkungan dan tentunya tak lepas dari dukungan dari istansi pemerintah yang membidangi sampah, termasuk itu lembaga riset dalam menjadikan sampah limbah plastik menjadi nilai guna. Saat ini berbagai upaya telah dilakukan oleh berbagai Lembaga riset/pemerintah dan lainnya dalam menyelesikan problem ini yakni sampah yang tak kunjung dapat di seleseikan.

Melalui upaya yang dapat dilakukan oleh Lembaga riset penelitian dan pengabdian khususnya dosen fakultas ekonomi Universitas Lancang Kuning melalui surat tugas LPPM Universitas Lancang Kuning Pekanbaru melakukan salah satu tri dharma perguruan tinggi yakni pengabdian. Adapun program ini dapat terlaksana dengan terbangunnya komunikasi aktif antar masyarakat/tokoh masyarakat dan pemuda juga pemudi dalam upaya untuk merealisasikan program ini, pemanfaatan limbah sampah plastik. Sasaran dari pengabdian ini yakni pemuda dan remaja masjid yang ada di sekitar lingkungan RT/RW 003/012 Kelurahan Sidomulyo Timur kecamatan Marpoyan Damai serta pelaksanaan dilaksanakan di masjid Darussakinah dan lapangan sekitanya.

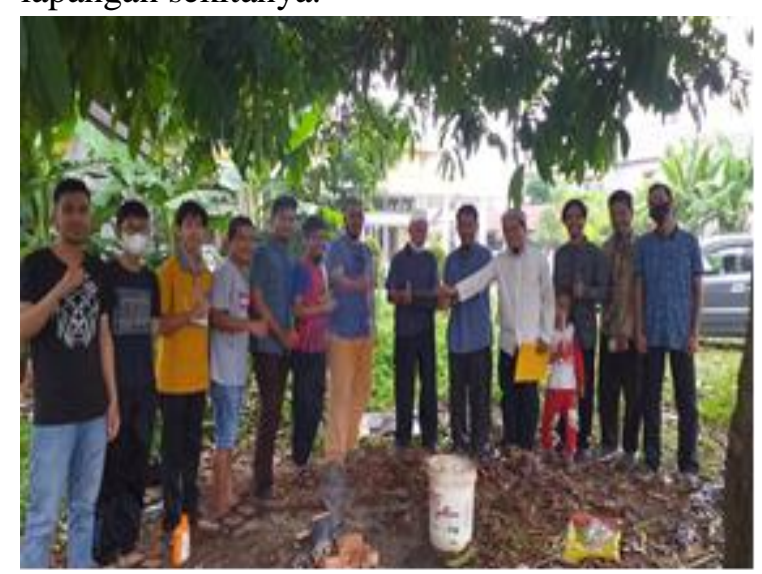

Gambar 2. Pengolahan limbah plastik "batu batako" Plastik

Pelaksanaan pengabdian dilaksankan pada hari ahad pagi jam 09.30 tanggal 26 September 2021. Adapun dalam pelaksanaan pengadian ini alhamdulillah dihadiri oleh tokoh masyarakat yang juga sekaligus Ketua RT/RW 002/012, Unsur masyarakat lainnya, serta unsur pemuda yang yang Dominan dalam pelaksanaa pengabdian dan pemuda juga sasaran utama dalam pengabdian pemanfaatan limbah sampah plastik ini. Dalam pengolahan pemanfaatan limbah ini kami tim pengabdian yang terdiri dari tiga tim dosen fakultas ekonomi universitas lancang kuning kami menghadirkan salah satu dosen dari fakultas ekonomi yang sudah memahami dengan baik akan seluk beluk dalam pengolahan limbah sampah plastik yang ada dikota Pekanbaru, yakni bapak Prama Widayat, S.E., M.M.

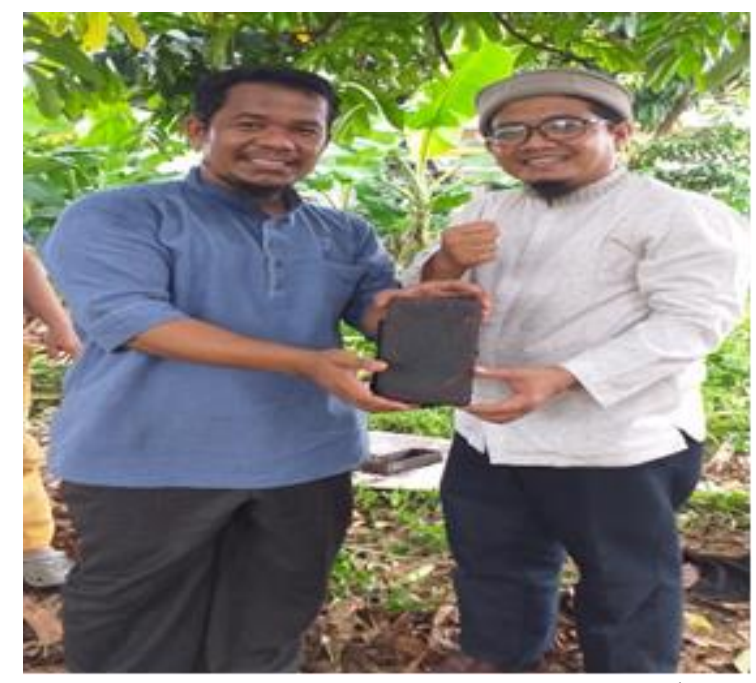

Gambar 3. Hasil pengolahan limbah plastik "batu batako" Plastik

Oleh karenanya untuk mengukur tingkat keberhasilan dalam pelasanaan pengabdian ini, upaya yang kami lakukan yakni memastikan sasaran utama yang target dalam pengabdian yakni pemuda sebanyak 6 orang atau paling banyak 8 orang pemuda, semua ini atas arahan dari pemateri, agar lebih efektivenya tingkat sasaran yang akan diberikan pelatihan dalam pengolahan limbah sampah plastik. Namun pada kenyataan dengan yang lebih target yang di inginkan, artinya disini adanya kaingin tahuan pemuda lainnya dalam penangganan limbah sampah plastik ini sebanyak sepuluh orang Pemuda dan satu tokoh masyarakat dan dewasa dua orang ada secara keseluruhan tiga belas orang peserta. 


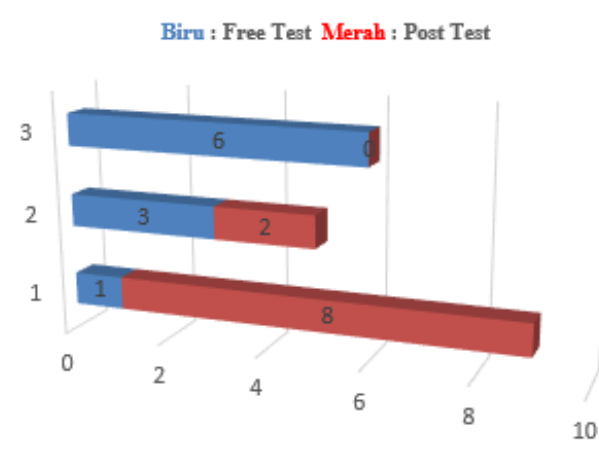

Gambar 4. Grafik Peningkatan Pengetahuan tentang Pengolahan Limbah Plastik

Sumber: Data Olahan 2021

Dari data lapangan yang dihimpun dan dilaksanakan, bahwasannya pengabdian yang telah dilaksanakan dapat diambil apa yang menjadi keinginan tim pengabdian terhadap masyarakat pada umumnya dan pemuda yang menjadi target dalam pelaksanaan pengabdian ini, data menunjukan peningkatan secara pengetahuan terhadap upaya pengenalan pengolahan limbah sampah plastik menjadi bahan yang bernilai guna dan memberikan nilai atas sampah selama ini tidak terpikirkan. Data membuktikan bahwasannya sebelum dan sesudah diberikan pengarahan serta praktek dilapangan membuktikan bahawasannya peningkatan pengetahuan dari peserta yang hadir, baik yang menyatakan iya, ragu ragu dan tidak.

Terjadinya peningkatan pengetahuan terhadap masyarakat tentang nilai manfaat dari limbah sampah plastik yang memberikan dampak lebih bermanfaat dan bernilai ketika apa yang selama ini tidak memberikan nilai akan memberikan nilai terhadap limbah tersebut. Hal ini juga dapat lihat tingginya antusias dari peserta untuk mengikuti pelatihan dari awal dan hingga akhir pelaksanaa pengabdian tersebut. Pelatihan dan peningkatan pengetahuan menjadi nilai tambah secara wawasan dan praktek dilapangan serta memberikan manfaat dari limbah yang selama ini selalu dibuang atau dibakar dan sebagainya. Sekarang menjadi perhatian dan pesona tersendiri ketika berhadapan dengan limbah berikutnya. Terjadinya perubahan mintdet terhadap limbah sampah plastik ini menjadi pengetahuan dan tantangan tersendiri dari peserta pelatihan.

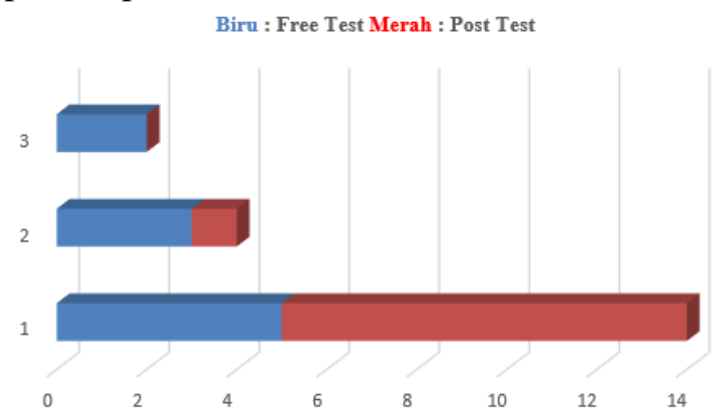

Gambar 5. Grafik Peningkatan Pemahaman tentang Pengolahan Limbah Plastik

Sumber: Data Olahan 2021

Dengan bertambahnya pengetahuan dari masyarakat akan pelaksanaan pengabdian ini tentang pemanfaatan limbah sampah plastik, tentunya akan bertambah lengkap dengan bertambahnya pemahaman masyarakat terhadap limbah sampah plastik tersebut. Hal ini tentu tidak lepas dari upaya tim pengabdian serta intruktur di lapangan yang berupaya untuk memberikan tingkat pemahaman akan kemanfaatan dari limbah sampah plastik tersebut. Hasil dari pelaksanaan pengabdian ini dapat dilihat dari data yang didapatkan dari masyarakat/responden merupakan hasil dari pemanfaatan limbah sampah plastik tersebut. Dimana dari hasil sebelum dan sesudah pelaksanaan pengabdian dapat dilihat dengan jelas dari data yang dipaparkan, membuktikan bahwasannya bertambahnya tingkat pemahaman masyarakat dan pemuda masjid yang berpartisipasi pelaksanaan pengabdian ini.

Berangkat dari pemahaman ini yang mengarah pada kesadaran dari masyarakat /pemuda masjid tentang kemanfaatan dari limbah sampah plastik tersebut. Dengan adanya kesadaran dari masyarakat/pemuda ini tentunya mengarah juga pada lingkungan sekitar, rumah tangga dan lingkungan yang lebih besar pada umumnya, minimal masyarakat dapat sadar dari bertambahnya pemahaman mereka tentang dampak positif negatif dari limbah sampah plastik ini. 
Hal ini juga terlihat dari antusias tokoh masyarakat yang hadir pada saat pelaksanaan pengabdian ini, dari ulasan pelaksanaan pengabdian tersebut muncul keinginan dari tokoh masyarakat tersebut, untuk bisa direalisasikan terutama yang sifatnya pribadi dan lingkungan disekitarnya tentang kemanfaatan dari pengolahan limbah sampah plastik ini. Hal ini tentunya tidak lepas dari bertambahnya pengetahuan dan pemahaman itu sendiri tentang manfaat dari limbah sampah plastik ini bila telah di olah dan bernilai guna. Keputusan pengolahan limbah plastik menjadi daya tarik sendiri nantinya Ketika munculnya kesadaran dari masyarakat untuk dapat menerapkannya terutama pada lingkungan terdekat.

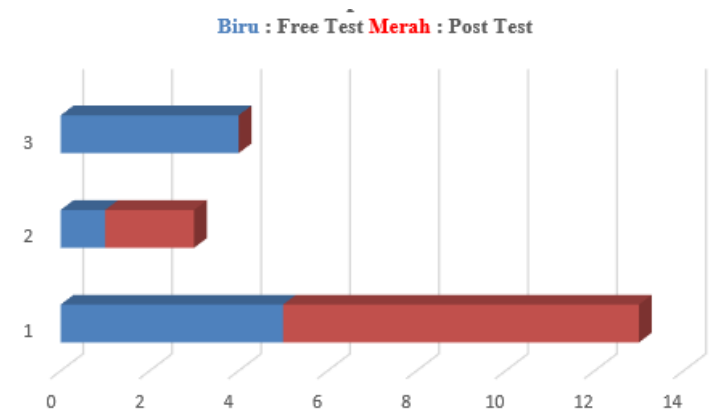

Gambar 6. Grafik Keputusan Pengolahan Limbah Plastik

Sumber: Data Olahan 2021

Seiring dengan bertambahnya pengetahuan dan pemahaman tentang pemanfaatan limbah plastic tentunya memberikan dampak pada pengambilan sebuah penerapan/kebijakan pemanfaatan dari limbah sampah plastik tersebut. Hal ini tentu ini tentu tidak lepas dari yang selama ini tidak peduli, tidak tahu dan lainnya limbah plastik inilah yang membuat masyarakat/pemuda tidak begitu memperdulikan sampah plastik ini. Seiring dengan adanya pelaksanaan pengabdian ini dapat dilihat dari antusias peserta/responden/masyarakat pelaksanaan pengabdian dan setelah hasil limbah itu menjadi sebuah produk yang bernilai guna dan menarik serta jarang di lihat atau bahkan tidak pernah sama sekali. Dimana limbah sampah plastik tersebut diolah menjadi sebuah batu yang mirip/menyerupai dengan "batu batako" yang pada umumnya terbuat dari pasir/tanah, namun yang di jumpai saat ini dari limbah sampah plastik.

Pemanfaatan limbah sampah plastik dalam bentuk batu batako, mungkin untuk kota Pekanbaru akan sangat sulit kita jumpai, hal ini tentu tidak lepas dari masih sedikitnya upaya untuk menjadikan sebuah yang akan memberikan sesuatu yang berbeda dan tidak pernah di pakai di berbagai tempat/lingkungan (Zhang et al., 2019). Hal inilah yang seharusnya menjadi alternatif nantinya dimana

Terlaksanaanya pengabdian ini terlihat dari antusias dari tokoh masyarakat yaitu $\mathrm{H}$. Zainuddin selaku ketua RT setempat yang menginformasikan pelaksanaan pengabdian. Agar masyarakat ikut bergabung dan berpastisipasi dalam pelaksanaan kegiatan pengabdian ini, karena melihat pentingnya informasi ini bagi masyarakat dalam memanfaatkan limbah sampah rumah tangga sehinggan limbah sampah plastik ini bisa dimanfaatkan dan diolah sendiri olah warga dan masyarakat dilingkungan RT tersebut.

\section{KESIMPULAN}

Dari pelaksanaan pengabdian ini didapatkan hasil yang menyatakan bahwasannya pemanfaatan limbah sampah plastik pada pemudan dan remaja masjid dilingkungan RT/RW 002/012 Kelurahan Sidomulyo Timur Kecamatan Marpoyan Damai, dapat ditarik kesimpulan sebagai berikut: (1) Bertambahnya pengetahuan dari masyarakat/pemuda masjid dan dilingkungan sekitarnya akan kegunaan dari kemampuan akan pengolahan limbah sampah plastik menjadi sesuatu yang berguna dan bermanfaat; (2) Bertambahnya pemahaman masyarakat akan limbah sampah plastik bilat ahu bagaimana mengolah limbah sampah plastik menjadi sebuah produk yang tidak bermanfaat menjadi sebuah tepat guna serta aman; (3) Munculnya keinginan dari masyarakat untuk dapat mengolah sampah plastik dengan sendirinya untuk dapat digunakan sebagaimana yang telah di pelajari dan terlihat mudah di 
terapkan secara pribadi serta lingkungan sekitarnya akan kemanfaatan dari pengolahan limbah sampah plastik tersebut.

\section{UCAPAN TERIMA KASIH}

Alhamdulillah, dan terima kasih kepada Lembaga penelitian dan pengabdian (LPPM) Universitas Lancang Kuning yang membantu proses dalam pelaksanaan pengabdian ini, baik secara anggaran dan dukungan lainnya, hingga pengabdian ini bisa terlaksana dan lancar serta besarnya harapan masyarakat untuk realisasi pengolahan sampah pada tahapan berikutnya.

\section{DAFTAR PUSTAKA}

Anuar Sharuddin, S. D., Abnisa, F., Wan Daud, W. M. A., \& Aroua, M. K. (2016). A review on pyrolysis of plastic wastes. Energy Conversion and Management, 115, 308-326. https://doi.org/10.1016/j.enconman.2016. 02.037

Budiarti, W., Susilowati, S., \& Farida, I. (2018). Upaya Pemanfaatan Sampah Plastik Kelompok Ibu-Ibu Dasawisama Gladiol 161 di Perumahan Magersari Permai , Kabupaten Sidoarjo Laporan Pengabdian Kepada Masyarakat. JURNAL KOMUNIKASI PROFESIONAL, 2(2), 156-168.

Horodytska, O., Valdés, F. J., \& Fullana, A. (2018). Plastic flexible films waste management - A state of art review. Waste Management, 77, 413-425. https://doi.org/10.1016/j.wasman.2018.04 .023

Ismanto, S. U. dan. (2016). Pengolahan Sampah Plastik Jenis PP, PET, dan PE menjadi Bahan Bakar Minyak dan Karakteristiknya. Syamsiro Jurnal Mekanika Dan Sistem Termal, 1(1), 713.

Li, X., Ling, T. C., \& Hung Mo, K. (2020). Functions and impacts of plastic/rubber wastes as eco-friendly aggregate in concrete - A review. Construction and Building Materials, 240, 117869. https://doi.org/10.1016/j.conbuildmat.201 9.117869

Liu, H., Liu, Y., Wang, H., Yang, J., \& Zhou, $X$. (2019). Research on the coordinated development of greenization and urbanization based on system dynamics and data envelopment analysis- $\mathrm{A}$ case study of Tianjin. Journal of Cleaner Production, 214, 195-208. https://doi.org/10.1016/j.jclepro.2018.12. 046

Ng, S. L. (2019). Predicting multi-family dwelling recycling behaviors using structural equation modelling: A case study of Hong Kong. Resources, Conservation and Recycling, 149(February), 468-478. https://doi.org/10.1016/j.resconrec.2019.0 6.007

Pakaya, S., \& Muhrim, M. (2020). PKM Kelompok Kerajinan Pengolahan Sampah Plastik Di Kecamatan Kota Tengah Kota Gorontalo. 4(2), 79-84.

Rakib, M., Thaief, I., \& Sanusi, D. A. (2019). Pelatihan kewirausahaan: Pengolahan sampah plastik menjadi produk bernilai jual bagi ibu-ibu rumah tangga dan remaja. Jurnal Dedikasi, 21(2), 124-127.

Wedayani, N. M. (2018). Studi Pengelolaan Sampah Plastik Di Pantai Kuta Sebagai Bahan Bakar Minyak. Jurnal Presipitasi : Media Komunikasi Dan Pengembangan Teknik Lingkungan, 15(2), 122. https://doi.org/10.14710/presipitasi.v15i2 $.122-126$

Zhang, H., Pap, S., Taggart, M. A., Boyd, K. G., James, N. A., \& Gibb, S. W. (2019). A review of the potential utilisation of plastic waste as adsorbent for removal of hazardous priority contaminants from aqueous environments. Environmental Pollution, $\quad x x x x, \quad 113698$. https://doi.org/10.1016/j.envpol.2019.113 698 